\title{
THE RISE AND FALL - AND POTENTIAL RESURGENCE - OF THE COMPARATIVE METHOD, WITH SPECIAL REFERENCE TO ANTHROPOLOGY
}

\author{
HENRIKA KUKLICK
}

\section{INTELLECTUAL RESISTANCE TO COMPARISONS}

Each of us has his or her standard academic questions, asked with tedious regularity of the presenters of papers at scholarly meetings. No names need be mentioned, but we all know a person whose usual ploy is to present a speaker with a summary of her paper, ask her if the summary is correct, and then ask for clarification of a point or two after being praised for his accurate summary. We also all know a person whose level of antisocial behaviour is tolerated in few places outside the seminar room, who will ask a speaker some variant of the question, "Why have I been obliged to listen to your stream of sentences that make no evident sense?" My own standard question is, "Compared to what?"

My point is that a comparative approach is always an option for me and for others of like mind. The sorts of papers most likely to provoke my question are those that consider a development (any development) in a specific national context, without any consideration of the possibility that the causal factors assumed to be critical in said national context may not be so. For example, historians of the United States have of late devoted some attention to the baseline assumption of the existence of "American exceptionalism", which informs a good deal of American scholarship. ${ }^{1} \quad$ The ingredients of the American exceptionalist argument that the United States has had a history unlike any other nation-state have been few and straightforward: the United States has been distinctive because it has had no hereditary aristocracy to impede upward social mobility of individuals who earn their leadership positions; the culture of the United States has been formed in a "melting pot" (or sometimes, of late, in a "salad bowl"), in which diverse traits of a population of immigrants have been blended in a fortuitous mixture of a congeries of elements gathered from everywhere; and an abundance of land on which the geographical frontier receded but (notwithstanding official pronouncements) never really closed has provided recurrent opportunities for ambitious individuals and social innovation. At the moment, in the popular version of the American exceptionalist argument, there is a fair amount of conversation that suggests that the 
United States is a nation uniquely guided and favoured by an interventionist Christian deity. Indeed, as historians of the development of the discipline of American history have informed us, employment as an academic historian was once contingent on professing this view. ${ }^{2}$ Perhaps international developments will cause this xenophobic line to moderate (if not disappear altogether) in popular discourse in the future.

What's wrong with thinking that there is something exceptional about the thesis of American exceptionalism? Never mind its unwarranted message that the United States has been free from class-based social strife. We also easily recognize that its implicit assumption that the United Status enjoys special status in the eye of God is found in other national histories. And comparison with the standard histories of other nation-states reveals many narrative elements that are similar in their particulars. For example, for more than two centuries Russians have argued (not without some apparent justification) that they have had in Siberia a frontier conducive to freedom and innovation. ${ }^{3}$ Histories of other white-settler societies — such as South Africa and Australia - have pointed to factors very similar to those invoked in many histories of the United States (especially those written for schoolchildren); white-settler narratives commonly celebrate egalitarian styles of personal relationships and unfettered opportunities for upward mobility - although, of course, the populations to which these generalizations apply have been implicitly understood to be males of European extraction - and Western (or at least Central) European extraction at that. ${ }^{4}$ Indeed, school textbook histories everywhere seem generically designed to impart pride in unique national virtues, and efforts to modify the moral lessons they convey invariably provoke controversies. ${ }^{5}$ In the versions of history taught to schoolchildren, if not also in writings of many professional historians, virtually every nation's history is an exceptionalist one.

\section{THE SPIRIT OF THE AGE}

By contrast, however, comparisons among nations seem to have been relatively frequent in the nineteenth century, when it was assumed that national histories fit general patterns. In Britain, for example, contemporary Britons and ancient Phoenicians were frequently equated. As Alexander Wilmot wrote in 1896:

[F]rom the fourteenth to the fourth century before Christ the Phoenicians...sent forth the most daring and successful fleets and colonies of antiquity...Their small territory required outlets for a redundant population... In all history there is no greater analogy than that between the Empire of Britain and that of Phoenicia at its culminating point of glory...6

In his introduction to Wilmot's book, the novelist H. Rider Haggard wrote that the Phoenicians were "this crafty, heartless and adventurous race...the English of the ancient world without the English honour". 7 Indeed, the British-Phoenician analogy was a commonplace in continental Europe throughout the nineteenth century. Moreover, the Phoenicians were not the only ancient peoples to whom Britons once compared themselves. Pondering the condition of their empire, they attempted 
to explain why Rome fell, and wondered how to avoid replicating Rome's errors. Considering ancient Greece, they weighed the merits of the social organizations of Athens and Sparta. ${ }^{8}$ (It is of interest that some academics of British origin who have taken positions in the United States, such as Paul Kennedy and Niall Ferguson, have embraced a similarly moral approach to historical analysis, preaching the lessons to be learned from Britain's imperial experience to the citizens of what is now an American empire in all but name.)

There is one obvious reason that Britain's educated classes were once wont to compare themselves with the classical ancients: they were educated in the classics. But this explanation is only a partial one. If one can speak in the intellectually vague term of the zeitgeist (and sometimes one must), the nineteenth century was a historically self-conscious age, aware that there was inevitably a "spirit of the age", in John Stuart Mill's phrase. ${ }^{9}$ And one can only understand the development of the comparative method in anthropology if one sees it as the product of an age with historicist sensibilities. Among the most important questions practitioners of this method asked was: Was it possible to achieve better understanding of the classical ancients who were responsible for laying the basis of western civilization by examining then-contemporary non-western peoples, who were presumed to be in at least some particulars analogous to the ancients?

I will discuss the comparative method in anthropology largely with reference to its use by practitioners who fell within the British sphere of influence. This is not because its practice was restricted to that sphere. The greatest of nineteenth-century American anthropologists, Lewis Henry Morgan (1818-81), worked in a style that resembled nineteenth-century British anthropologists, although he was not an "armchair" scholar in the mould of his British contemporaries; they were able to achieve eminence in anthropological circles without leaving the comforts of home, drawing on information collected by others to produce their generalizations. ${ }^{10}$ Morgan was something of a field naturalist, so that direct observation informed his analysis of Native Americans (and of beavers); arguably, he also reasoned with greater intellectual rigour and used more elaborate documentation than was employed by most British scholars; the informants who imparted their knowledge of exotic peoples both to Morgan and to British armchair anthropologists were apt to be rather contemptuous of the generalizations produced by the latter. ${ }^{11}$ And the greatest of late-nineteenth/early-twentieth century French social scientists, Émile Durkheim (1858-1917) — an armchair scholar whose works are still considered relevant to contemporary disciplinary inquiries by anthropologists, sociologists, and others ${ }^{12}$ also practised a variant of the comparative method. Certainly, differences obtained among practitioners of this method in different national contexts. But the case of British proto-anthropologists who used the comparative method should serve as generally illustrative.

\section{THE SOCIAL STRUCTURE OF COMPARATIVE RESEARCH}

The comparative method in nineteenthcentury anthropology was born of four 
elements, none of which was peculiar to anthropology: one, an approach to collecting information; two, an established style of dividing intellectual labour; three, a methodological orientation; four, an aesthetic of generalization and explanation.

Collecting information: There was a standard way to collect information about any given specific object, creature, or practice that was found in many places the questionnaire. The most important of anthropologists' questionnaires was the volume jointly published by the British Association for the Advancement of Science and the Royal Anthropological Institute at irregular intervals from 1874 to 1951, Notes and Queries on Anthropology (it was originally entitled Notes and Queries on Anthropology for the Use of Travellers and Residents in Uncivilized Lands). ${ }^{13}$ This was not the only anthropological questionnaire circulated; individuals such as J.G. Frazer, for example, drew up and distributed their own questionnaires. But it is important to recognize that Notes and Queries on Anthropology merely elaborated a general form. This had taken shape no later than the late seventeenth century, when some Fellows of the Royal Society printed and circulated a questionnaire to elicit information about the natural and built features of the environments of England and Wales. ${ }^{14}$

Consider the periodical entitled simply Notes and Queries, a vehicle for inquiring minds who were curious about virtually anything. On March 18, 1854, for example, it published a query from a reader who seemed bent on acquiring confirmation of his judgement that mackerel were blind (his explanation for their lack of interest in the flies he cast in the waters in which he wished to catch them). ${ }^{15}$ On November 28, 1857, Notes and Queries published a request for information about the career of a small child who had at some time been exhibited in London, in the irises of whose eyes was said to be visible the name "Emperor Napoleon". ${ }^{16}$ And on February 1, 1862, it published readers' responses to a question about the number of societies past and present in which human corpses were ceremonially buried in the foetal position. One of these responses came from Sir John Lubbock (a baronet, later Lord Avebury), a scientific polymath with special expertise in insects, who knew Charles Darwin as a neighbour, family friend and intellectual mentor, and who was a longserving member of Parliament as well as a wealthy banker. Lubbock's many accomplishments included being the first president of the Anthropological Institute of Great Britain and Ireland (later the Royal Anthropological Institute), formed in 1871 from the union of the previously warring Ethnological Society of London and the Anthropological Society of London. ${ }^{17}$ That Lubbock was among the readers of Notes and Queries, along with the incompetent mackerel fisherman, surely indicates that this publication reached a broad audience.

Then, there existed the informal questionnaire, such as the letters of inquiry that Charles Darwin mailed to his global network of naturalist-informants, without whose assistance he could never have gathered the wealth of data from which he produced such works as the on the Origin of Species in $1859 .{ }^{18}$ Last, but hardly least, there were informationgathering kits, such as those for collecting insects that would-be purchasers of specimens distributed to travellers to foreign 
parts (such as naval officers and traders); these included operating instructions, as well as the materials necessary to kill, preserve and store insect specimens without mutilating them. ${ }^{19}$ Of course, individual scholars supplemented the material they gleaned from systematic inquiries with information they happened upon in various ways, but it is the existence of a variety of routinized forms of deliberate solicitation of information that is significant.

Division of labour: There was a clear division of labour between collectors of information and analysts thereof, which represented a division along class lines roughly, the division between players and gentlemen, respectively. Those who received compensation for their scientific activities, as collectors often did, were not considered capable of judging evidence dispassionately - and also were not, in any event, "clubbable", almost invariably being considered unfit for leadership roles in the societies of enthusiastic amateurs who dominated many spheres of British scientific life until the twentieth century. Consider the case of Paul du Chaillu, a French-born traveller to equatorial Africa in the middle of the nineteenth century (who had various financial supporters, including, for example, the Academy of Natural Sciences in Philadelphia). When he made public appearances in London, his descriptions were greeted with scepticism and he himself was widely believed to be something of a cad: his reports of African peoples and their natural environment, which included the first eyewitness observations of the gorilla, were accepted only after authentication by gentlemenscientists. The gentlemen-scientists had no empirical basis for their judgements, basing them on their assessments of $\mathrm{du}$ Chaillu's character. Evidently, their high social status counted for more in scientific circles than du Chaillu's research experience. $^{20}$

I must emphasize that to report this standard division of labour is not to suggest that we must identify with the view of the gentlemen-amateurs, or that we must believe that the collectors who served gentlemen-scientists regarded their role as that of mere servants. As Anne Secord has ingeniously documented, working-class collectors who supplied nineteenth-century gentlemen-botanists with specimens had considerable scientific expertise, as well as genuine commitment to scientific inquiry. ${ }^{21}$ But no matter what were the satisfactions working-class collectors derived from their scientific labours, their voices were not audible in prestigious scientific circles.

Methodological orientation: The collection of evidence from thither and yon somehow had to be rationalized as a reasonable procedure. Intellectual historians must begin with the working principle that the figures we study were at least as smart as we are, and so we should not be surprised to learn that many nineteenthcentury anthropologists were aware that their informants were not presenting them with what the philosopher of science calls "brute facts" — as she customarily does, immediately prior to declaring that there are no such things. At least some of anthropologists' disciplinary ancestors recognised that, as the philosopher Mary Hesse has memorably stated, theories are always "underdetermined by facts" - a point especially relevant in accounts of paradigm change (and to which we will return). ${ }^{22}$ 
In 1870, for example, John Lubbock observed that the particular perspectives of individuals shaped their reports, saying, "Whether any given writer praises or blames a particular race, depends at least as much on the character of the writer as on that of the people." ${ }^{23}$ Indeed, attention to observer bias had a considerable lineage in science, dating at least to the astronomers' definition of the so-called personal equation in the 1820s, a phenomenon of which Sir John was surely aware, since his father was a distinguished astronomer. ${ }^{24}$ That is, by the end of the eighteenth century, astronomers had noted that individual observers varied in their reaction times to, say, the transit of a star, and astronomers subsequently undertook to calculate patterns of variations among individuals, specifying individuals' differences, so as to achieve inter-subjective measures by which vital matters such as the setting of clocks could be resolved. ${ }^{25}$

It is no accident, to use historians' once-canonical locution, that Francis Galton delivered descriptions of some of his most important statistical innovations to the Anthropological Institute, of which he was President from 1885 to 1888 , as he did when he described the normal frequency distribution (also known as the bell curve) which should be observable for any variable, ranging from, say, height to life expectancy; he intended his statistics to be useful in describing the phenomena anthropologists examined, including cultural and biological traits. In his history of the development of statistics in Britain, Donald MacKenzie emphasizes that Galton and others, most notably Karl Pearson, who developed such statistical measures still in use as the correlation coefficient, were motivated by their desire to docu- ment patterns of human heredity so that they could promulgate eugenic strategies for improving the physical and mental condition of the British population. ${ }^{26}$ But Galton was surely aware of anthropologists' problem in reconciling disparate reports in order to formulate generalizations. And if he did not say explicitly that he expected his statistical techniques to solve anthropologists' methodological problem, another sometime president of the Anthropological Institute, E. W. Brabrook, did, stating that anthropologists need not trouble themselves with inconsistencies in the reports they received from "every direction", but could trust "rather to the general laws of numbers than to the skill of individuals to eliminate errors" ${ }^{27}$

An aesthetic of generalization: The comparative method in anthropology was born in an era in which it was assumed that all satisfactory explanations were historical ones. It was not merely the case that historical analogies were frequently made, and history examined for its moral lessons, as I have already discussed. The general idea of evolution, once called "transformism", antedated Darwin's conceptualization of it and was applied to description of various natural phenomena. Consider the practice of embryology in the last quarter of the nineteenth century, when it was a highly prestigious area of research in the biological sciences. Embryological research was animated by the recapitulation hypothesis, which could be applied more or less strictly. Compatible with Darwinism (although also reconcilable with other developmental schemes), this was the idea that ontogeny recapitulated phylogeny, that the development of each individual recapitulated the history of the development of the species to which 
it belonged. Thus, examination of embryonic growth patterns was expected to yield answers to the fundamental questions of species' evolution. For example, a development in an embryo that proved just a transient phase in the progress of an organism to its infant stage could indicate whether degeneration was just as important a feature of its evolutionary history as progress - a possibility much debated at the end of the century. (In the developmental scheme so influentially promulgated by Herbert Spencer in the latenineteenth century, progress generally meant a movement from simplicity to complexity. $)^{28}$ To give another example of the use of the recapitulation hypothesis, Sigmund Freud's Lamarckian explanation of the structure of the individual psyche conjured up real human experiences in the remote historical past that would be recapitulated in childhood maturation which could constitute degeneration (or at least arrested development) if the full course of the species' development was not followed. ${ }^{29}$

In the first decades of the twentieth century, all manner of varieties of historical explanations would be dismissed as such, as expressions of what philosophers termed the "genetic fallacy" — a pejorative phrase expressing the idea that the origins of any given institution in the past had no necessary relevance to understanding the operations of that institution in the present. Nowadays, facile dismissals of assertions as expressions of the genetic fallacy are rarely heard, although we can easily conjure up illustrations of arguments that might be dismissed as based on the genetic fallacy. For example, we should not devalue Galton and Pearson's statistics because the two men were motiv- ated by eugenic objectives, since their statistics can be used in all manner of research projects. At the same time, we can also see that the historical antecedents of some present practices may be meaningful in contemporary contexts. And historical explanations are back in fashion. Regardless, appeals to historical explanations are themselves historical phenomena; they have seemed more plausible in some eras than in others.

\section{THE COMPARATIVE}

\section{ANTHROPOLOGICAL PROJECT}

What kinds of questions did anthropologists hope to answer with their comparative method? They wanted to trace the development of institutions, such as replacement of the practice of tracing descent from the mother by the supposedly superior practice of tracing descent from the father. Consider what was arguably the single most important article published by E.B. Tylor, whose appointment as Reader in Anthropology at Oxford in 1884 (the first such position in Britain) ${ }^{30}$ represented a decisive shift toward the professionalization of the subject. Published in 1888, Tylor's article, "On a Method of Investigating the Development of Institutions, Applied to Laws of Marriage and Descent", used information gathered about societies all over the world, to which societies Tylor assigned grades on a unilinear scale of evolution, analyzing data with a method he called adhesions" (which we would call "correlations"). Tylor thought he could thus determine how transitions from one stage of evolution to another were effected; his most notable finding was that the practice of couvade - in which the father of a child apparently 
suffers birth pangs during the course of its birth, and is sympathetically attended - denoted progress toward creation of family structures in which fathers assumed their appropriate responsibilities. ${ }^{31}$

Anthropologists also wanted to determine what relationship obtained between the biological and social development of the human species. Consider the resolution of the problem first raised in 1858 by William Gladstone, the future prime minister: How should one interpret the recurrent use of such descriptions as "winedark sea" in Homer? Perhaps it was legitimate to analogize ancient Greeks to contemporary primitives - to assume that all populations negotiated an identical course of biological as well as social development, and that the ancient Greeks' perceptual sensibilities had not yet matured to the degree observed among modern peoples. Perhaps ancient Greeks really could not distinguish between the colours of the sea and of wine, a conjecture supposedly confirmed by babies' apparent initial preference for red over blue (remember that the development of babies' sensibilities supposedly recapitulated the maturation pattern of the entire human species). This argument was not discredited until W.H.R. Rivers put it to empirical test during the 1898 Cambridge Anthropological Expedition to Torres Straits, which was organized by the man who would occupy Cambridge University's first position in sociocultural anthropology, A.C. Haddon. ${ }^{32}$ The Torres Straits expedition was the first venture to take British scientists into the field to do their own anthropological research, and it afforded Rivers the opportunity to observe that the islanders had no difficulty seeing blue - although it was not their favourite colour. ${ }^{33}$
Or, anthropologists wanted to use empirical evidence to chart the emergence of superior morality and spirituality - and to compel recognition of "survivals" of earlier, irrational and immoral times "survivals" which could then be deliberately eliminated. Theirs was anthropology as the "reformer's science", as E.B. Tylor often spoke of it. And self-understanding and consequent self-conscious reform was J.G. Frazer's objective when he disseminated his interpretation of Baldwin Spencer and F.J. Gillen's 1899 classic Native Tribes of Central Australia - Australia's pioneering contribution to the development of anthropological field-research method even though, as it happened, he disagreed with Tylor in his interpretation of Spencer and Gillen's findings. Understanding Arrernte ignorance of the facts of procreation and their totem ceremonies to be analogous to Christian belief in the virgin birth of Jesus and the ceremony of the Eucharist, Frazer believed that he had exposed survivals of truly primitive habits, persisting in what was a supposedly rational age. ${ }^{34}$ I will shortly return to consideration of the international anthropological controversy that Frazer's views provoked.

Clearly, the unilinear evolutionist model that relied on the comparative method was not really historical but historicist - or, at least, historicist in the pejorative sense. Cross-cultural research was used by anthropologists to document the assumption that differences between societies were matters of degree rather than of kind; that some societies had simply advanced further along the teleological trajectory of human progress than others. Why was this research mode abandoned? It would be easy to say that anthropologists dismissed their model and method 
rationally because these were proven defective. Reasoned judgement was not irrelevant to intellectual change, but we should briefly pause in our consideration of anthropology's paradigm shift to ask, "Compared to what?"

Consider the case of economists, political scientists and sociologists who have attempted to formulate guidelines for modernizing non-western societies. Among these, the recapitulation hypothesis remained respectable for roughly half a century longer than it did for anthropologists. In fact, one could say that anthropology differentiated itself from other social science disciplines by being first on the mark to reject this hypothesis - and that "modernization" theory ceased to be respectable as much in consequence of ridicule animated by political concerns as anything else. ${ }^{35}$ Or consider the contemporary primatologists whose projects represent a residue of the objective that anthropologists abandoned when they jettisoned the recapitulation hypothesis scientists who imagine that they can reconstruct the behaviour of earliest humankind on the basis of their observations, divided though they may be by certain disputes. Which particular primate species constitutes the best prototype of humans' ancestors? What sorts of observations are reliable - in the laboratory or in the field? If the observer is in the field, should she make the ground her vantage point or can she see natural behaviour while being an intrusive presence perched in a Land Rover? Where is the demarcation boundary between humans and other primates if the latter can be taught to communicate in some form of language? Likewise, what does it mean to be human if primates have been tool-users and have even developed culture ${ }^{36}$ The historian of nineteenthcentury anthropology feels weary as she watches intellectual history repeating itself among primatologists.

\section{THE DECLINE OF THE COMPARATIVE METHOD}

But I return to the history of anthropology within the British sphere of influence. It reveals widespread dissatisfaction with the theory and method required for comparative analysis by the end of the nineteenth century. In the 1892 edition of Notes and Queries on Anthropology, for example, C.H. Read observed that the passing traveller could not obtain "even superficial answers" to the questions anthropologists wanted answered; only persons with "long-continued residence among a native race" were trustworthy informants. $^{37}$ And when in 1902 A.C. Haddon described Spencer and Gillen's Native Tribes of Central Australia as "the best book of its kind about any people", he signalled the claims to authority of a new style of anthropologist, persons such as Baldwin Spencer and himself, trained scientists, whose specialized observational skills were more reliable (and more rapid) means to collect accurate information than the intellectual habits formed during "long continued residence among a native race", and whose primary task was to accumulate detailed knowledge of delimited areas which might be, but need not be, used in comparative analyses. ${ }^{38}$ Authoritative judgements entailed personal experience of field research among the peoples the anthropologist wished to describe periods of research that became possible with the development of academic careers, such as Haddon and Spencer enjoyed. 
Field trips of a year or more would become the anthropological gold standard in the twentieth century, when anthropologists had better opportunities for financing them with the patronage of private philanthropies and government agencies, but in earlier times it became possible to do fieldwork for the simple reason that academic lives were punctuated by long breaks. ${ }^{39}$ Much of the research for Native Tribes was done during Spencer's 1896-97 summer vacation from his position as Professor of Biology at the University of Melbourne, when he was able to work with Gillen in Central Australia. There, Gillen, a civil servant who was given leave to work with Spencer, was the effective administrator of the area's Aborigines, and had accumulated a good deal of ethnographic knowledge during two decades' residence.

Haddon urged researchers to understand exotic peoples from the "native point of view", an injunction echoed by Spencer and Gillen when they argued that anthropologists must enter "into the mental attitude of the native". Though the "genealogical method" Rivers developed for the Torres Straits expedition proved remarkably durable, however, Haddon's venture did not provide an imitable model. Taking seven men to spend roughly seven months living for periods of variable length on one or another portion of an island cluster, dividing investigative labour among themselves, the Torres Straits expedition constituted a hybrid genre of anthropology. The six volumes of Reports Haddon edited — five published before World War I, and the last (Volume I) in 1935 - received largely favourable reviews, but they were, in part, exercises in old-style research, relying on evidence that Haddon solicited from afar to supplement the information his team had gathered in the field. Moreover, while teamwork remained common in natural scientific practice (and one could say that practitioners of the comparative method were members of informally constituted teams), teamwork did not become anthropology's ideal method. Rather, Spencer and Gillen's Native Tribes became an exemplar. It represented an approximation of the anthropological method that would soon be conventional: a comprehensive study of a delimited area, based on sustained fieldwork conducted by one or two people (if the latter, often a husband and wife), portraying a population's distinctive character.

The significance of Native Tribes in the era of its publication was rather different, however. In 1913, for example, Bronislaw Malinowski said of Spencer and Gillen's studies that "half the total production in anthropological theory ha[d] been based upon their work, and nine-tenths affected or modified by it". Native Tribes inspired an intense international debate, arguably the most international of controversies in anthropology's history. As E. Sidney Hartland had observed in 1900, so pervasive was the debate that the "quiet noncombatant student" was "astonished to find himself in the theatre of war", assaulted by "jarring theories and conflicting claims", and "searching in vain" for "a bomb-proof burrow". The debate was framed by J.G. Frazer (broker of the book's publication by Macmillan). It was predicated on the assumption that indigenous Australians were the most primitive of living peoples, whose totemism was (somehow) at the base of civilization's highest achievements - monogamous 
marriage and truly spiritual religion. Sustained with intensity through the mid1920s, the debate proved irresolvable in Frazer's terms. Pondering conflicting interpretations of totemism, anthropologists rejected unilinear models of social evolution like Frazer's; if nothing else, they agreed that it was impossible to grade peoples according to the rate at which they were making progress from savagery to civilization because evolution everywhere did not fit a single pattern.

In the early twentieth century, bounded populations of professional anthropologists emerged, developing various theoretical schemes; international intellectual exchanges were impeded by language barriers. Some (although certainly not all) of these anthropologists insisted that the indigenous peoples of their countries such as those in North America and Australia - were quite distinctive, defying comparison with groups elsewhere; it is interesting to note that these included Spencer and Gillen, who lamented the absence of a special term for the Australian variety of totemism, which they considered unlike any other. Some anthropologists, particularly those in Germanspeaking areas, as well as those influenced in North America by the German-born and -trained Franz Boas, dedicated themselves to varieties of historical analyses, but their understanding of historical change was informed by attention to particularities of time and place. In the United States, for example, sociocultural anthropologists chose a truly historical approach, emphasizing the unique characteristics that distinguished peoples from one another; Boas himself decried efforts to produce profound generalizations from cross-cultural comparisons (his students would later disagree). In sum, concerted efforts to use the comparative method to solve a problem that all participants in the debate over totemism had initially agreed was important had resulted in consensus that totemism was not a unitary phenomenon wherever it was found, that evolution did not follow a standard course, and that the comparative method was impracticable. ${ }^{40}$

Twentieth-century British anthropologists did not abandon their predecessors' aspirations to formulate scientific generalizations. But they repudiated the notion that laws of development that obtained in all societies. Instead, they attempted to document the postulate that all societies were fundamentally identical, all of them sharing certain essential properties, all performing the same basic functions. And they reasoned that the point of studying so-called simple (or technologically underdeveloped) societies was not that these societies were qualitatively different from technologically sophisticated ones but that they were relatively simple to study, a point also made by Émile Durkheim (among others). ${ }^{41}$

That is, the functionalists who dominated British anthropology from the late 1920s to the 1960s dismissed efforts at historical explanations as nonsensical as expressions of the genetic fallacy. Consider the 1911 pronouncement of the young Malinowski, who would shortly become a protégé of Baldwin Spencer (although he would see Spencer as his enemy within a decade):

[T] he interest of an exact scientist should focus on understanding and penetrating the mechanism and essence of social phenomena as they exist at present and are 
accessible to observation, and not in order that these phenomena should serve as the riddle of a prehistoric past about which we cannot know anything empirically. ${ }^{42}$

Defining the fundamental principle of functionalist anthropology as that "in every type of civilisation, every custom, material object, idea and belief fulfills some vital function...represent[ing] an indispensable part within a working whole", Malinowski said in 1926 that evolutionary progress "consist[ed] not in a sequence of different forms changing one into another, but in a better adaptation of an institution to its function" [emphasis mine]. ${ }^{43}$

A quarter-century later, Haddon and Rivers's most distinguished student, A.R. Radcliffe-Brown, who was Malinowski's (sometimes antagonistic) co-conspirator in the establishment of functionalist paramountcy, was still making similar arguments, saying that there was no point in attempting to chronicle the histories of non-literate societies because such societies did not leave reliable written records. But even if accurate histories could be plotted somehow, they would be irrelevant to the primary goal of social anthropology. As he said: "History, in the proper sense of the term, as an authentic account of the succession of events in a particular region over a particular period of time, cannot give us generalizations." $\mathrm{He}$ endorsed cross-cultural comparisons, however, saying that the comparative method was "one by which we pass from the particular to the general, from the general to the more general, with the end in view that we may in this way arrive at the universal, at characteristics which may be found in different forms in all human societies" ${ }^{4}{ }^{4}$ In short, the functionalists' position, as articulated with exceptional clarity by Radcliffe-Brown, was to support crosscultural research, but to suggest that whatever insights might be gleaned through use of the comparative method would not likely challenge the generalizations the anthropologist could produce from a single case study, since all societies were fundamentally alike.

But then, during the 1960s and 1970s, the functionalist model became a target of ridicule, much as the evolutionist model had been a target before it. Certainly, one might say that reports of functionalism's death have been greatly exaggerated, or, at least, that functionalist analysis persists in truncated form. No self-respecting anthropologist today would open herself to ridicule by postulating that any given society constitutes a bounded whole, in which all component parts are integrated in a mutually reinforcing system; but she will, nevertheless, describe interdependent beliefs and practices (as, indeed, she should). ${ }^{45}$ One might also note that certain of evolutionists' assumptions were never thoroughly dispelled, either; not the least of these being that those societies which it is no longer politically correct to call "primitive" are in some sense doomed, bound to lose their idiosyncratic characteristics as they are caught up in the whirlwind of globalization; my point is that it should not be assumed that these societies experience historical change in a distinctive way.

Regardless, contemporary anthropologists' definition of their purview has changed, returning to one approximating that of the nineteenth century. Once again, 
anthropologists study the entire world, not just technologically unsophisticated peoples - although the student who writes his Ph.D. thesis on homelessness in New York City, say, or on the conditions of innovation in a biotechnology company, may find herself hard-pressed to find an academic job as an anthropologist in the United States, since many anthropology departments continue to place high value on fieldwork in remote places. Interestingly, in Britain, unlike in the United States, sociocultural anthropologists who do their Ph.D. fieldwork in their own society are as likely to find academic employment as those who do research abroad. ${ }^{46}$ But, then, our young, non-traditional anthropologist may find herself non-academic employment, as many anthropologists do nowadays, in which her anthropological skills may prove to have commercial value. Not the least of her marketable skills (and certainly not the only one) is her capacity to appreciate cross-cultural variation, an important asset in the global marketplace: consider the anthropologist whose job it is to appreciate local differences in the use of ostensibly culture-free technology, such as computers. ${ }^{47}$ In some disciplines - say, economics, biology and physics - practical application has enhanced the discipline's prestige in the eyes of both practitioners and laypersons. Perhaps academic anthropology will now abandon the haughty disdain for applied work that it has sustained for more than half a century.

\section{POSSIBILITIES OF THE FUTURE}

Returning to academe proper, however, we observe that disciplinary boundaries are now being renegotiated in ways condu- cive to cross-cultural, comparative analysis. Disciplinary genres are blurring. From its text alone, a reader may not be able to judge whether any given article was written by a historian or an anthropologist (or some other academic type), and practitioners of different disciplines have appropriated each other's theories and methods. Anthropology itself is becoming more international, although there are certainly distinct cleavages; British anthropologists who object to their colleagues' increasingly closer intellectual ties to Americans (formed not least because there are now many Americans employed in British departments) have looked for like-minded associates in continental Europe. ${ }^{48}$ And over the past decades there have been widespread intellectual trends. Anthropologists - and others - have encouraged attention to the peculiarities of the local, while historians have been especially concerned to establish patterns of everyday lives among the ordinary folk of the past. Nowadays, it seems that the focus of past decades on accumulating knowledge about the peculiarities of the local has provoked a reaction; various types of scholars are now producing sweeping surveys of times and places. They are asking genuinely comparative questions about differences and similarities. But genuinely cross-cultural, comparative research poses technical difficulties. It requires not only a wealth of accumulated knowledge about a range of places but also particular skills, such as the command of a number of languages and the ability to decipher old styles of handwriting. The most promising way to do cross-cultural research may be to form collaborating teams. Thus, we may revive another structural feature of nineteenth-century 
scholarship, albeit one in which the social stratification in the division of academic labour will be based on the professional standards of the modern university, rather than on the general class structure.

\section{ENDNOTES}

1 See, for example, Dorothy Ross, The Origins of American Social Science, New York: Cambridge University Press, 1991, which argues that belief in American exceptionalism has been sustained by all varieties of social science practised in the United States.

2 See Peter Novick, That Noble Dream, New York: Cambridge University Press, 1988.

3 See Mark Bassin, Imperial Visions: Nationalist Imagination and Geographical Expansion in the Russian Far East, 1840-1865, Cambridge: Cambridge University Press, 1999.

4 See, for example, Richard White, Inventing Australia, Sydney: George Allen and Unwin, 1981.

5 See, for example, Felicity Barringer "Africa's Claim to Egypt's History Grows More Insistent", The New York Times, "Week in Review", February 4, 1990, 6; Clyde H. Farnsworth, "Aborigine Enters History Books, 100 Years Late", The New York Times, August 15, 1997, A4; Ethan Bronner, "Israel's History Textbooks Replace Myths With Facts", The New York Times, August 14, 1999, Al, A5; Joseph Kahn, "Where's Mao? Chinese Revise History Books", The New York Times, September 1, 2006, Al, A6; Hassan M. Fattah, "Beirut Memo: A Nation With a Long Memory, but a Truncated History", The New York Times, January 10, 2007, A4.

6 Alexander Wilmot, Monomotapa (Rhodesia), London: Greenwood Press, 1969 (facsimile of the original 1896 edition), 118.

7 H. Rider Haggard, in Ibid., xvii.

${ }^{8}$ For one exercise in documenting Britons' tendency to analogize their society to classical ancient societies, see Richard Jenkyns, The Victorians and Ancient Greece, Cambridge, MA: Harvard University Press, 1980.

${ }^{9}$ He first used it in an article that appeared in seven parts in The Examiner between January and May 1831.

10 Figures prominent in anthropological circles in the latter part of the nineteenth century, such as E.B. Tylor, Francis Galton and T.H. Huxley, did undertake journeys to exotic parts when they were young men. In their day, however, high reputations in an- thropology were not contingent on having had personal contact with the subjects of scholarly analyses, as would be the case in the twentieth century.

11 For example, the Australian civil servant A.W. Howitt and his collaborator Lorimer Fison, a retired missionary, who provided information to both Morgan (whom they called "their chief") and to a number of British armchair scholars, disparaged the work of the latter. See, for example, George W. Stocking, Jr., Victorian Anthropology, New York: The Free Press, 1987, 236.

12 See Karen E. Fields's preface to her new translation of Émile Durkheim, The Elementary Forms of Religious Life, New York: Free Press, 1995 [originally 1912], xvii-lxxiii.

13 For a discussion of Notes and Queries on Anthropology, see Stocking, Victorian Anthropology, 258.

14 See E.G.R. Taylor, “Robert Hooke and the Cartographical Projects of the Late Seventeenth Century (1666-1696)", The Geographical Journal 90 (1937): 529-40.

15 Notes and Queries Vol.9, No. 229 (March 18, 1854), 245.

16 Ibid. Vol.4, 2nd ser., No. 100 (November 18, 1857), 434.

17 Ibid. Vol.1, 3rd ser., No. 5 (February 1, 1862), 99.

18 On Darwin's information-gathering practices, see Janet Browne, Charles Darwin: The Power of Place, New York: Random House, 2002, passim.

19 On the material culture and formalized instructions for collecting natural specimens, see Anne Larsen, 'Not Since Noah: The English Scientific Zoologists and the Craft of Collecting, 1800-1840', Ph.D. Dissertation, Princeton University, 1993.

20 Stuart McCook, "'It may be the truth, but it is not evidence': Paul du Chaillu and the Legitimation of Evidence in the Field Sciences" in Henrika Kuklick and Robert Kohler, eds., Science in the Field, issue of Osiris n.s.11 (1996): 177-200.

21 Anne Secord, "Science in the Pub: Artisan Botanists in Early Nineteenth-Century Lancashire", History of Science 32 (1994): 269-315.

22 I am, of course, referring to the dramatic changes that can occur in the theories and practices of scientific enterprises that have been called "paradigm shifts" ever since the publication of Thomas Kuhn, The Structure of Scientific Revolutions, Chicago: University of Chicago Press, 1962.

23 John Lubbock, On the Origin of Civilisation and the Primitive Condition of Man, London: Longmans, Green, 1870, 296.

24 Stocking, Victorian Anthropology, 150. 
25 In the received history of experimental psychology, astronomers' recognition and calculation of variation among individual observers marks the beginning of their enterprise. See Edwin G. Boring, $A$ History of Experimental Psychology, Second Edition, New York: Appleton-Century-Crofts, Inc., 1950, 31, 134-5.

26 See Donald MacKenzie, Statistics in Britain, 1865-1930, Edinburgh: University of Edinburgh Press, 1981, 16-7.

27 E.W. Brabrook, “On the Organisation of Local Anthropological Research", Journal of the Anthropological Institute 22 (1892): 271.

28 See, for example, Adrian Desmond, Huxley: The Devil's Disciple, London: Michael Joseph, 1994, 90, 125-6, 184, 190-9. For a survey of various British and European notions about degeneration in the late nineteenth and early twentieth centuries, see Daniel Pick, Faces of Degeneration, Cambridge: Cambridge University Press, 1989.

29 Freud wrote a number of implicitly Lamarckian analyses of this sort. For one example, see his Totem and Taboo: some points of agreement between the mental lives of savages and neurotics, translated by James Strachey, London: Routledge and Kegan Paul, 1950 [originally 1913].

30 In 1896, Tylor was given a personal professorship, retiring in 1909; his successor, R.R, Marett, retired as a Reader.

31 E. B. Tylor, “On a Method of Investigating the Development of Institutions, Applied to Laws of Marriage and Descent", Journal of the Anthropological Institute 18 (1888): 245-72.

$32 \mathrm{He}$ was appointed University Lecturer in Ethnology in 1900; in 1909, he became a Reader, and retired as such in 1926. At the time of the expedition, he was Professor of Zoology at the Royal College of Science in Dublin.

33 See my The Savage Within, New York: Cambridge University Press, 1991, esp.146-9.

34 For explication of Frazer's views, see my “'Humanity in the chrysalis stage': Indigenous Australians in the anthropological imagination, 1899-1926", British Journal for the History of Science 39 (2006): 535-68.

35 See, for example, Michael E. Latham, Modernization as Ideology: American Social Science and "Nation Building" in the Kennedy Era, Chapel Hill: University of North Carolina Press, 2000.

36 The pioneering study is Donna Haraway's Primate Visions: Gender, Race, and Nature in the World of Modern Science, New York: Routledge, 1989. For a recent survey that attends to these issues, see Robert N. Proctor, "Three Roots of Human Recency", Current Anthropology 44 (2003): 213-29.
37 C.H. Read, "Prefatory Note" to Part II, "Ethnography", John Garson and Charles Hercules Read, eds., Notes and Queries on Anthropology, Second Edition, London: The Anthropological Institute, 1892, 87.

38 A.C. Haddon to Baldwin Spencer, 5 May, 1902, in the Spencer Papers, Pitt Rivers Museum, Oxford, Box 1. Near-contemporaries, Spencer and Haddon were both trained as biologists, and were professional rivals as such before they became like-minded anthropologists. Haddon came second in the competition for Spencer's Melbourne chair. It is worth noting that when the natural history sciences (ranging from anthropology to zoology) differentiated at the turn of the twentieth century, they embraced a common method - the detailed study of a delimited area. For Haddon's rallying cry to embrace this method (as well as an account of the vicissitudes of his career), see my "Islands in the Pacific: Darwinian Biogeography and British Anthropology", American Ethnologist 23 (1996): 611-38. On the field method embraced by the natural history sciences, see my "After Ishmael: The Fieldwork Tradition and its Future" in Akhil Gupta and James Ferguson, eds., Anthropological Locations, Berkeley: University of California Press, 1997, 47-65. For one statement of the claim that their training made anthropologists more accurate and efficient observers of native peoples than such long-resident observers as colonial officials, see C.G. Seligman, quoted in Richard Temple, Anthropology as a Practical Science, London: G. Bell and Sons, Ltd., 1914, 44. Seligman participated in the Torres Straits expedition.

39 This is not to say that fieldworkers such as Haddon did not require grants to finance their fieldwork, but their patrons were not very generous. They had to exercise considerable ingenuity in order to assemble sufficient funds, and might supplement their grants through personal efforts. Haddon, for example, collected ethnographic artefacts to sell to museums; see my "Islands in the Pacific", op. cit.

40 This discussion of the totemism controversy summarizes my "'Humanity in the chrysalis stage", op. cit., and all of the quotations in my discussion are used in this article. The most famous illustration of Boas's students' efforts to produce comparative generalizations about societies is Ruth Benedict's Patterns of Culture, New York: Houghton Mifflin Company, 1934.

41 For a succinct summary of the differences between British and American anthropology, see George W. Stocking, Jr., "The Basic Assumptions of Boasian Anthropology" in his The Shaping of American Anthropology, New York: Basic Books, 1974, 1-20.

42 Bronislaw Malinowski, "Totemism and Exogamy" in Robert Thornton and Peter Skalník, eds., The Early Writings of Bronislaw Malinowski, translated by 
Ludwik Krzyzanowski, Cambridge: Cambridge University Press, 1993 (from the portion of the essay originally published in 1911), 140.

43 Bronislaw Malinowski, "Anthropology", The Encyclopaedia Britannica, 13th Edition Supplement, London and New York: The Encyclopaedia Britannica Company, 1926, 133.

44 A.R. Radcliffe Brown, "The Comparative Method in Social Anthropology", Journal of the Royal Anthropological Institute 81 (1951): 22.

45 See, for example, Kingsley Davis and Robert Merton's definitions of functionalist analysis, by which any demonstration of association between one social element and another counts as functionalist analysis. By this token, of course, unilinear evolutionist analyses were also functionalist, since they assumed the interdependence of the component parts of any stage of evolution. But consider Paul Rabinow, Reflections on Fieldwork in Morocco, Berkeley: University of California Press, 1977. Recognized as a pioneering example of a new anthropological genre, it purports to challenge all functionalist conventional wisdom, but nevertheless invokes some all-pervasive Moroccan cultural spirit, and accounts for the phenomena Rabinow observed in terms of an implicit whole.

46 Jonathan Spencer, Anne Jepson, and David Mills, "Career Paths and Training Needs of Social Anthropology Research Students. ESRC [Economic and Social Science Research Council] Research Grant RES-00023-0220. End of Award Report", unpublished manuscript, 2005, 9.

47 See, for example, the work of Genevieve Bell, who earned her Ph.D. in anthropology at Stanford in 1997, who works for Intel Research. Observing 100 households in 19 cities in seven countries in Asia and the Pacific, she has observed differences in use of technology that Intel hopes to apply to future designs. See Michael Erard, "For Technology, No Small World After All", The New York Times, May 6, 2004, "Circuits" section, G5.

48 See, for example, Adam Kuper, "Alternative histories of British social anthropology", Social Anthropology 13 (2005): 47-64. 